\title{
Molecular investigation of Neorickettsia risticii in trematodes and snails in a region with serological evidence of this agent in horses, state of Rio de Janeiro
}

\author{
[Pesquisa molecular de Neorickettsia risticii em trematódeos e moluscos em região com evidência sorológica \\ do agente em equinos, estado do Rio de Janeiro] \\ R.L. Costa ${ }^{1}$, G.L.V. Vitari ${ }^{1}$, C.B. Silva ${ }^{1}$, M.P. Peckle ${ }^{1}$, M.S. Pires ${ }^{1}$, S.V.P.B. Brandolini ${ }^{2}$, \\ J. Pinheiro' ${ }^{2}$ C.L. Massard ${ }^{1}$, H.A. Santos ${ }^{1 *}$ \\ ${ }^{1}$ Instituto de Veterinária - DPA - Universidade Federal Rural do Rio de Janeiro - (UFRRJ) - Seropédica, RJ \\ ${ }^{2}$ Instituto de Biologia - DBA - Universidade Federal Rural do Rio de Janeiro - (UFRRJ) - Seropédica, RJ
}

\begin{abstract}
In Brazil, some studies have indicated that Neorickettsia risticii circulates in horses, but it is unclear which are the possible intermediate vectors of this bacterium in the country. The aim of this study was to use molecular techniques in order to analyze the presence of $N$. risticii in snails and larval stages of trematodes in farms in a region with a history of seroreactive horses towards this bacterium, in Rio de Janeiro, Brazil. Convenience sampling was used in the studied region. The collected snails were exposed to incandescent light (60W) for 2-4 hours in order to investigate trematodes in larval forms. Deoxyribonucleic acid (DNA) was extracted from snail tissue and trematode. Real-time PCR (qPCR) technique was used to investigate the presence of a 16S rRNA gene fragment of $N$. risticii. Snail specimens $(\mathrm{n}=410)$ were collected from 11 horse-breeding farms, and the following species were identified: Melanoides tuberculata, Pomacea sp., Biomphalaria tenagophila, Physa acuta, Drepanotrema anatinum and Biomphalaria straminea. Only $3.17 \%(\mathrm{n}=13 / 410)$ of the collected snails were infected by trematodes. The cercariae obtained from these snails were classified as Megalourous cercariae, Pleurolophocercus cercariae and Furcocercous cercariae. There was no amplification of the target DNA of $N$. risticii in the snail and trematode samples tested by qPCR. Based on these data, the transmission of $N$. risticii by trematodes using these snail species in this region does not appear to occur or occurs at very low rates. Thus, further studies are needed in order to clarify which species of invertebrate hosts are infected by this bacterium and potentially participate in the transmission chain of equine neorickettsiosis in the state of Rio de Janeiro, Brazil.
\end{abstract}

Keywords: equine neorickettsiosis, molecular diagnosis, qPCR, intermediate hosts

\section{RESUMO}

No Brasil, estudos apontam a circulação de Neorickettsia risticii em equinos, contudo não estão claros quais os possíveis vetores intermediários dessa bactéria no país. O objetivo do presente estudo foi analisar a presença de $\mathrm{N}$. risticii, utilizando-se técnicas moleculares, em caramujos e estágios larvais de trematódeos em propriedades rurais de uma região com histórico de equinos sororreativos para essa bactéria, no Rio de Janeiro, Brasil. Uma amostragem por conveniência foi utilizada na região de estudo. Os caramujos coletados foram expostos à luz incandescente (60W) durante duas-quatro horas para a investigação de trematódeos nas formas larvais. A extração de ácido desoxirribonucleico (DNA) foi realizada em tecidos de caramujos e trematódeos. A técnica de PCR em tempo real (qPCR) foi utilizada para investigar a presença de um fragmento do gene $16 \mathrm{~S} r R N A$ de N. risticii. Foram coletados 410 espécimes de caramujos de 11 propriedades com criações de equinos, sendo identificadas as seguintes espécies: Melanoides tuberculata, Pomacea sp., Biomphalaria tenagophila, Physa acuta, Drepanotrema

Recebido em 9 de outubro de 2015

Aceito em 20 de abril de 2016

*Autor para correspondência (corresponding author)

E-mail: huarrisson@yahoo.com.br 
anatinum e Biomphalaria straminea. Apenas 3,17\% $(n=13 / 410)$ dos caramujos identificados estavam infectados por trematódeos. As cercárias obtidas desses caramujos foram classificadas em Megalourous cercariae, Pleurolophocercus cercariae e Furcocercous cercariae. Não foi observada a amplificação do DNA-alvo de N. risticii, por meio da qPCR, em nenhuma das amostras de caramujos e trematódeos testadas. Com base nesses dados, a transmissão de N. risticii por trematódeos que utilizam as espécies de caramujos nessa região parece não ocorrer ou ocorre a taxas muito reduzidas. Portanto, novos estudos são necessários para elucidar quais espécies de hospedeiros invertebrados se infectam por essa bactéria e potencialmente participam da cadeia de transmissão da neorickettsiose equina no estado do Rio de Janeiro, Brasil.

Palavras-chave: neorickettsiose equina, diagnóstico molecular, qPCR, hospedeiros intermediários

\section{INTRODUCTION}

Neorickettsia risticii (Holland et al., 1985) Dumler et al., 2001 (previously described as Ehrlichia risticii), a bacterium of the Anaplasmataceae family, is the etiological agent of equine neorickettsiosis (Pusterla et al., 2003), also known as Potomac horse fever (Rikihisa et al., 1984). This bacterium preferentially invades cells of the mononuclear system, such as monocytes, tissue macrophages and intestinal epithelial cells (Rikihisa et al., 1984).

This disease affects horses at all ages and the clinical signs vary, but include fever, depression, anorexia, laminitis, colic, and acute diarrhea (Holland et al., 1985).

Studies indicate that transmission to horses occurs through oral ingestion of the trematodes infected with N. risticii (Madigan et al., 2000; Mott et al., 2002). These helminths might be free-living in the water that horses drink, attached to vegetation or encysted in intermediate hosts (Barlough et al., 1998). Snails are always used by digenetic trematodes as the first intermediate host. Aquatic insects are used as a second intermediate host (Chae et al., 2000). The horse might accidentally ingest these insects containing metacercariae infected with $N$. risticii and acquire the infection (Mott et al., 2002). Insectivorous birds and bats are definitive hosts for trematodes that are vectors for $N$. risticii (Pusterla et al., 2003; Gilbson et al., 2005). Studies have shown that snails of the families Pleuroceridae (genus Juga), Planorbidae (genus Planorbella) and Hydobriidae (genus Heleobia) have a direct relationship with the transmission of this bacterium (Pusterla et al., 2000a; Coimbra et al., 2005; Pusterla et al., 2013). These snails have been found to be positive for N. risticii using nested PCR (nPCR) and real-time PCR
(qPCR) as diagnostic techniques (Barlough et al., 1998; Pusterla et al., 2000b).

Geographical distribution of equine neorickettsiosis in the United States has been well demonstrated (Palmer et al., 1986). Clinical and serological evidence shows that the disease also occurs in Canada, Brazil, Uruguay, and some countries in the Europe (Van Der Kolk et al., 1991; Dutra et al., 2001; Baird and Arroyo, 2013). In Brazil, compatible cases with the clinical disease were firstly described in the state of Rio Grande do Sul (Dutra et al., 2001; Coimbra et al., 2006). Serological evidence has also indicated that the agent circulates in horses in the states of Santa Catarina, São Paulo and Rio de Janeiro (Ferrão et al., 2007; Moreira et al., 2013).

Only snails of the genus Heleobia have tested positive for $N$. risticii using the PCR technique in southern Brazil. This genus has been indicated as participant in the transmission chain of the equine neorickettsiosis in Brazil (Coimbra et al., 2005). There is a need for further studies relating the bacterium to other possible intermediate hosts in Brazil, especially in areas with serological evidence of its circulation. The aim of the present study was to detect $N$. risticii DNA in larval trematodes and snails that are present in natural and artificial sources of water, on horsebreeding farms in the Itaguaí microregion, state of Rio de Janeiro, using qPCR as a diagnostic technique.

\section{MATERIAL AND METHODS}

This study was conducted between January and May 2013, in the municipalities of Seropédica and Mangaratiba ( $43^{\circ} 46^{\prime} 31^{\prime \prime} \mathrm{W}$ and $22^{\circ} 51^{\prime} 08^{\prime \prime}$ $\mathrm{S})$, which are located in the Itaguaí microregion of the state of Rio de Janeiro, Brazil. These 
municipalities were selected because of a previous study (Roier, 2011) which showed seroreactive horses to $N$. risticii in this region. Each collection point was georeferenced using the global positioning system (GPS; eTrex 30, Garmin ${ }^{\circledR}$, Kansas, USA) (Fig. 1). The Itaguaí microregion is characterized as tropical, with dry winters and rainy summers (Aw), with a hot and humid climate in general.

The farms were selected due to the presence of grazing areas and at least one source of water, such as lakes, rivers, streams, ponds and artificial water bodies. Convenience sampling of snails was carried out in these municipalities.

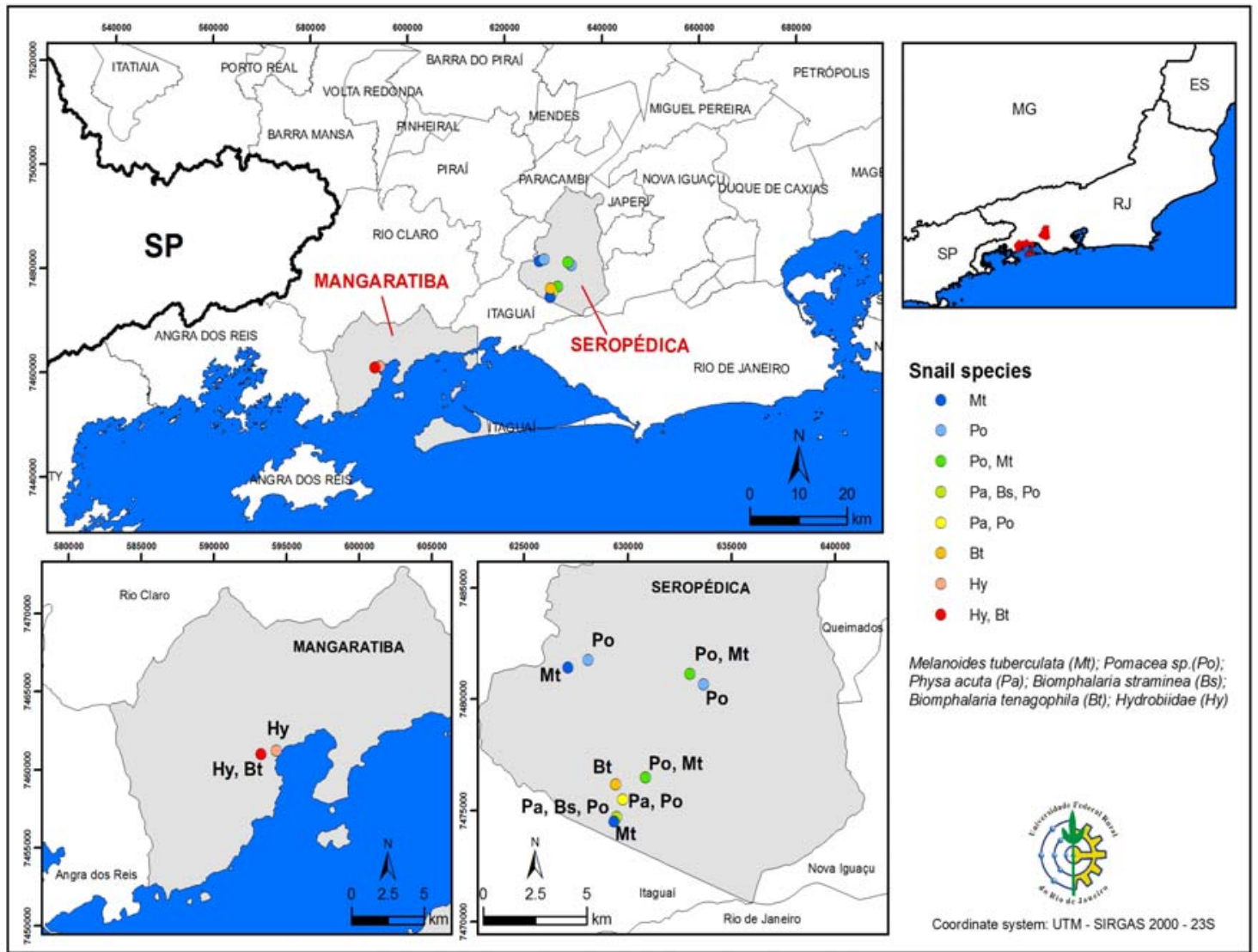

Figure 1. Geographical location of the areas where the snails were collected, according to the species and the municipality in the state of Rio de Janeiro.

The snails were collected using $2 \mathrm{~mm}$ fine-mesh netting and were transported to the laboratory. They were separated according to the genus and then, the snails were identified in species using conchology and anatomical dissections with the assistance of the Laboratório Nacional de Referência em Malacologia do Instituto Oswaldo Cruz (LNRM/ IOC/FIOCRUZ-RJ).

The snails were removed from their shells and were sectioned into four anatomical divisions: gonads (containing a small portion of the digestive gland), digestive gland, cephalopodal mass, and pallial cavity. These anatomical parts were grouped into pools containing 10 specimens (divided according to genus, sexual dimorphism and collection site), and were stored at $-80^{\circ} \mathrm{C}$ until DNA extraction.

Larval trematodes in the snails were surveyed as described by Coutinho (1950). The snails in which no cercariae were observed after exposure to light were kept in the dark until the next day and they were subsequently reexamined to ascertain which larval forms presented nocturnal activity. 
The larval forms of trematode were fixed in acetic acid 1:2 (AFA) and stained with Delafield hematoxylin (Merck, Darmstadt, Germany) for morphological identification. To determine the group, the larval forms were classified according to morphometric characteristics using an optical microscope (Olympus BX51 ${ }^{\circledR}$, Pennsylvania, USA) coupled to the $\mathrm{Cell}^{\wedge} \mathrm{D}$ software (Olympus Europe Software Informer ${ }^{\circledR}$, Pennsylvania, USA). The identification of species was based on morphological characteristics (Freitas, 1977).

Different anatomical regions of the snails, such as their digestive glands, gonads, cephalopodal mass and pallial cavity, were separated as described previously, in order to perform DNA extraction. Each sample was weighed on a precision balance and $15 \mathrm{mg}$ were macerated using a glass rod. Genomic DNA was extracted using a commercial kit, in accordance with the manufacturer's recommendations (Wizard genomic DNA purification kit from tissue, Promega ${ }^{\circledR}$, Madison, USA).

Larval trematodes were placed in polypropylene tubes containing $2 \mathrm{~mL}$ of distilled water. The tubes were centrifuged at $6,000 \mathrm{~g}$ for 4 minutes and DNA extraction was performed on the sediment, using a commercial kit (Wizard genomic DNA purification kit, Promega ${ }^{\circledR}$, Madison, USA).

All of the DNA samples were quantified using a spectrophotometer (NanoDrop ND-2000 ${ }^{\circledR}$, Thermo Fisher Scientific Inc., Massachusetts, USA). They were diluted to $100 \mathrm{ng} / \mu \mathrm{L}$ and stored at $-20^{\circ} \mathrm{C}$ until molecular analysis.

Neorickettsia risticii DNA from snails and larval trematodes was detected using the TaqMan realtime PCR system in the StepOnePlus ${ }^{\circledR}$ equipment (Applied Biosystems, California, USA), in order to amplify a fragment of $85 \mathrm{bp}$ (base pairs) of the 16S rRNA gene (Pusterla et al., 2000b). Samples with cycle quantification $(\mathrm{Cq})$ values below or equal to 40 cycles were considered positive. The reactions were performed in duplicate on different plates with a final volume of $20 \mu \mathrm{L}$, containing: 1X TaqMan ${ }^{\circledR}$ Universal PCR Master
Mix (Applied Biosystems ${ }^{\circledR}$, California, USA), $0.6 \mathrm{mM}$ of each primer, $0.2 \mathrm{mM}$ of the probe and $100 \mathrm{ng}$ of total DNA. The positive control sample was obtained from DH82 cell culture infected with $N$. risticii, removed from glass slides prepared for indirect immunofluorescence (Fuller Laboratories, California, USA). The slide was scraped and the contents were eluted in PBS solution. DNA extraction was performed subsequently using the DNeasy blood and tissue kit (Qiagen, Valencia, California, USA), in accordance with the manufacturer's recommendations.

The distribution of snails by municipalities and the morphometric data of the studied trematodes were submitted to descriptive analysis in the BioEstat 5.0 software (Ayres et al., 2007).

These procedures were approved by Comissão de Ética na Pesquisa da Universidade Federal Rural do Rio de Janeiro (COMEP/UFRRJ), under protocol number $364 / 2013$ and process number 23083.003989/2013-69.

\section{RESULTS}

The taxonomy classifications of the collected snails are shown in Tab. 1. A total of 410 snails were collected from the horse-breeding farms in the Itaguaí microregion. Among the species that were identified, Melanoides tuberculata (Muller, 1774) was the most frequent (Fig. 2), representing $71.7 \%(n=294 / 410)$ of the collected snails, followed by Pomacea sp. (Perry, 1810) with a frequency of $10.97 \% \quad(n=45 / 410)$. Biomphalaria straminea (d'Orbigny, 1835) was the less frequent species, with only one specimen collected. These snails were deposited in the snail collection of IOC/Fiocruz-RJ under numbers 8260 to 8276 . It was observed that $M$. tuberculata occurred in all of the municipalities analyzed, while $B$. straminea and $P$. acuta (Draparnaud, 1805) were observed only in the municipality of Seropédica. Likewise, Drepanotrema anatinum (Orbigny, 1835) and Hydobriidae (Stimpson, 1865) were observed only in the Mangaratiba municipality. 
Table 1. Taxonomy classification of the snails collected in the Itaguaí microregion, Seropédica, and Mangaratiba municipalities separately, state of Rio de Janeiro, Brazil

\begin{tabular}{lccccccc}
\hline \multirow{2}{*}{ Snails } & \multicolumn{2}{c}{ Total area } & \multicolumn{2}{c}{ Seropédica } & \multicolumn{2}{c}{ Mangaratiba } \\
\cline { 2 - 7 } & $\mathrm{N}$ & $(\%)$ & $\mathrm{N}$ & $(\%)$ & $\mathrm{N}$ & $(\%)$ \\
\hline Melanoides tuberculata & 294 & 71.70 & 260 & 76.47 & 34 & 48.57 \\
Pomacea sp. & 45 & 10.97 & 45 & 13.23 & - & - \\
Drepanotrema anatinum & 15 & 3.65 & - & - & 15 & 21.43 \\
Biomphalaria tenagophila & 27 & 6.58 & 11 & 3.23 & 16 & 22.86 \\
Biomphalaria straminea & 1 & 0.24 & 1 & 0.29 & - & - \\
Physa acuta & 23 & 5.61 & 23 & 6.76 & - & - \\
Hydobriidae & 5 & 1.25 & - & - & 5 & 7.14 \\
\hline Total & 410 & 100.0 & 340 & 100.0 & 70 & 100.0 \\
\hline
\end{tabular}

Larval trematodes were found in $3.17 \%$ $(n=13 / 410)$ of the snails collected in the studied area. Regarding the snail species that were naturally infected by trematodes, $25.92 \%$ belonged to $B$. tenagophila $(\mathrm{n}=7 / 27), 1.70 \%$ to M. tuberculata $(\mathrm{n}=5 / 294)$, and $20 \%$ to Hydobriidae $(\mathrm{n}=1 / 5)$.

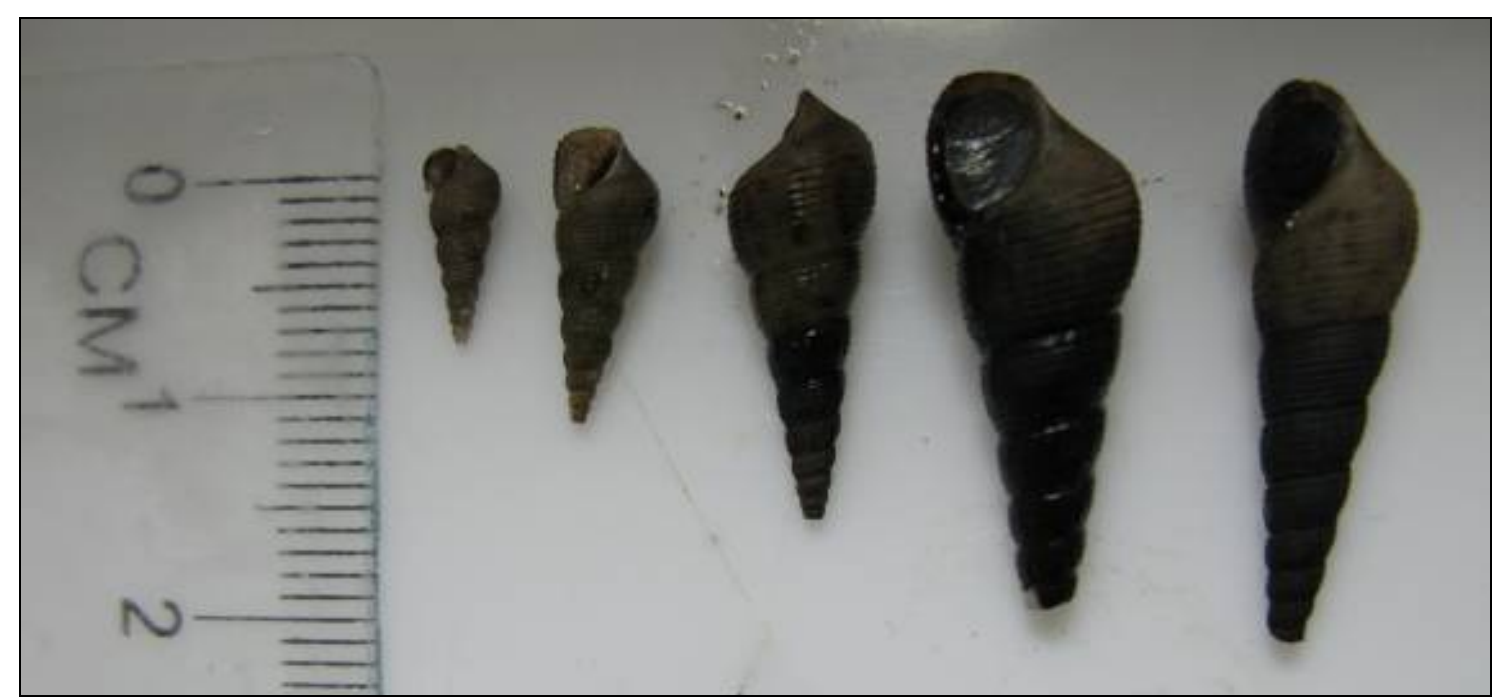

Figure 2. Specimens of Melanoides tuberculata collected in the Itaguaí microregion, state of Rio de Janeiro.

Regarding the municipalities, the highest frequency of snails infected by trematodes was observed in Mangaratiba, at a rate of $4.28 \%$ $(n=3 / 70)$, followed by Seropédica, with $2.94 \%$ $(n=10 / 340)$ of frequency. It was possible to detect trematode larvae, rediae, cercariae, and metacercariae in the digestive gland and cephalopodal mass of the parasitized snails. Morphometric data relating to cercariae morphotypes of infected snails are shown in Tab. 2.

Among the thiarids, the presence of several cercarie morphotypes was observed (Fig. 3). Morphotype 1 was characterized as the Megalourous cercariae group, infecting 1.02\% $(n=3 / 294)$ of the collected snails. Curiously, the metacercariae had a piriform shape and were observed only once, since their main feature was rapid encystment, which occurred in about one hour. Morphotype 2 was characterized as the Pleurolophocercous cercariae group and was found parasitizing $M$. tuberculata specimens at a frequency of $0.68 \%(n=2 / 294)$. Morphotype 3 was obtained from $B$. tenagophila and its cercariae were characterized as Furcocercous cercariae. Although a single specimen of morphotype 4 was also observed infecting Hydobriidae snails, it was not possible to stain and measure the specimen collected, because of the rapid degradation of the material that occurred through the staining process. 
Molecular investigation...

Table 2. Trematode stage, anatomical structures and morphometric data obtained in relation to the three cercariae morphotypes of infected snails that were collected in the Itaguaí microregion, state of Rio de Janeiro, Brazil

\begin{tabular}{lccccc}
\hline \multirow{2}{*}{ Stage } & Anatomical & Parameter & Type 1 & Type 2 & Type 3 \\
\cline { 4 - 6 } & structure & measured & $\mathrm{M} \pm \mathrm{SD}$ & $\mathrm{M} \pm \mathrm{SD}$ & $\mathrm{M} \pm \mathrm{SD}$ \\
\hline \multirow{6}{*}{ Cercariae } & $\mathrm{L}$ & $\mathrm{W}$ & $309.7 \pm 71.1$ & $174.3 \pm 4.2$ & $154.8 \pm 72.3$ \\
& $\mathrm{HO}$ & $\mathrm{D}$ & $55.0 \pm 48.3$ & $88.0 \pm 1.3$ & $37.8 \pm 27$ \\
& $\mathrm{OS}$ & $\mathrm{D}$ & $43.4 \pm 14.4$ & $20.6 \pm 3.5$ & - \\
& $\mathrm{VS}$ & $\mathrm{L}$ & $46.1 \pm 1.0$ & $101.8 \pm 7.9$ & $125.7 \pm 3.1$ \\
& $\mathrm{TA}$ & $\mathrm{W}$ & $21.9 \pm 1.8$ & $7.9 \pm 3.5$ & $18.8 \pm 0.3$ \\
& $\mathrm{DO}$ & $\mathrm{D}$ & - & $6.3 \pm 1.0$ & - \\
\hline
\end{tabular}

$\mathrm{L}=$ length, $\mathrm{W}=$ width, $\mathrm{D}=$ diameter, $\mathrm{OS}=$ oral sucker, $\mathrm{VS}=$ ventral sucker, $\mathrm{RO}=$ right ocellus, $\mathrm{LO}=$ left ocellus, $\mathrm{BO}=$ body, $\mathrm{TA}=$ tail, $\mathrm{M}=$ mean, $\mathrm{SD}=$ standard deviation

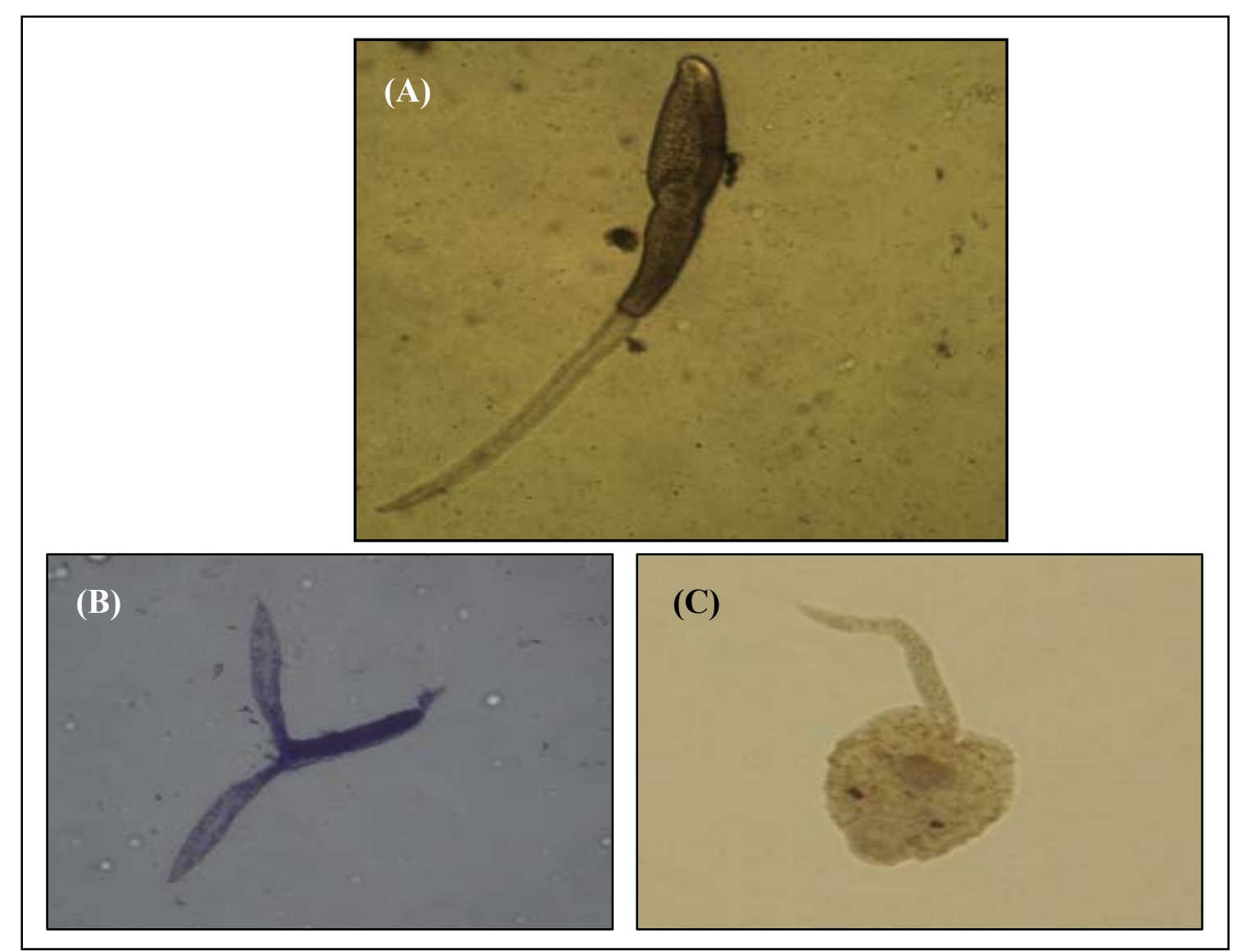

Figure 3. Cercariae morphotypes observed amongst infected Melanoides tuberculata collected in the Itaguaí microregion, state of Rio de Janeiro. (A) Megalourous cercariae; (B) Furcocercous cercariae; (C) Pleurolophocercous cercariae (400X magnification under an optical microscope).

Real time PCR analyzes on the snail samples showed that there was no amplification of $N$. risticii DNA. Similarly, no amplification of the 16S rRNA gene of $N$. risticii from trematode samples was observed.

\section{DISCUSSION}

In the present study, the target DNA of $N$. risticii in snail tissues and larval trematode samples was not detected. Previous studies have shown the 
movement of this bacterium between horses in the Itaguaí microregion, Rio de Janeiro state (Roier, 2011; Moreira et al., 2013). Furthermore, clinical evidence of equine neorickettsiosis has been reported in the same state (Ferrão et al., 2007). These results do not rule out the possibility of this bacterium infection in trematodes in the studied region, with very low prevalence.

It is well known that this agent has a relatively low prevalence in snails, even in areas with a history of neorickettsiosis in horses. Studies conducted in the United States have shown that the positivity rates of snails infected by $N$. risticii range from 0.7 to $12.5 \%$, even in endemic areas for the disease (Barlough et al., 1998; Pusterla et al., 2000a; Pusterla et al., 2013). In Brazil, a study conducted by Coimbra et al. (2005) showed that the frequency of snails infected by this bacterium was $13.3 \%$ in a region with a history of neorickettsiosis in horses. Furthermore, the percentage of infected snails can be influenced by certain biological factors, such as the type and maturation status of snail and trematode vectors, the period of the year and the region of study (Pusterla et al., 2000a).

The biology of the transmitters is associated with seasonality, and this influence affects the distribution of equine neorickettsiosis. In the United States, Palmer et al. (1986) observed that this disease occurred in the hottest months of the year (June to September), a period compatible with greater availability of snails. In addition, occurrences of equine neorickettsiosis were associated with wetlands, large river valleys and low areas near large lakes or irrigation ditches (Palmer et al., 1986; Dutra et al., 2001; Coimbra et al., 2006). Although the present study was conducted during the warmer months and in areas with characteristics similar to those already described, the presence of $N$. risticii DNA was not observed in any of the snail samples analyzed. This fact highlights the low prevalence of this bacterium in snails, in areas with a history or serological evidence of equine neorickettsiosis (Barlough et al., 1998; Pusterla et al., 2000a; Chae et al., 2003; Pusterla et al., 2013). It is important to mention that the rate of snail infection by $N$. risticii is related directly to the trematode infection rate. In the present study, the trematodes infection rate in snails was very low $(3.17 \%)$.
Recent studies have shown that different genera of snails are involved in the equine neorickettsiosis transmission cycle. In the United States, Juga sp., Planorbella sp., Stagnicolla sp. and Elimia sp. were considered to be the main species of freshwater snails associated with the life cycle of the digenetic trematode vectors of $N$. risticii (Kanter et al., 2000; Pusterla et al., 2000a; Pusterla et al., 2013). In Brazil, so far, only the genus Heleobia has been correlated with the equine neorickettsiosis cycle in the state of Rio Grande do Sul (Coimbra et al., 2005). None of these species were observed in the present study, but the mollusk fauna collected corroborate the findings of Thiengo et al. (2001). Melanoides tuberculata was the most common species of snail in this region. However, this species has not been incriminated as a snail vector of $N$. risticii in other studies. It is possible that other genera or species of snails are related to the transmission of $N$. risticii in the state of Rio de Janeiro.

Interestingly, B. straminea and B. tenagophila were found in the studied area. Both species are a public health concern given that these are intermediate hosts of the nematode Schistosoma mansoni, which is the etiological agent of schistosomiasis in humans.

None of the trematodes were positive for $N$. risticii, although Furcocercous-type cercariae were observed, which have already been identified as a vector for this bacterium in other studies (Chae et al., 2003; Park et al., 2003). The absence of the bacterium in these helminths may be related to agent specificity for its hosts, and also to transmission capacity for subsequent generations, when infected (Greiman et al., 2013).

Other intermediate hosts such as aquatic insects may act as an infection source to a trematode hosting the bacterium and to accidental hosts, as horses (Madigan et al., 2000). Chae et al. (2000) described 13 species of aquatic insects that might be directly related to the trematode vector cycle in Northern California. In Brazil, few studies have been conducted focusing in other possible intermediate hosts of trematode vectors beside the snails (Coimbra, 2010). Moreover, some studies have shown involvement of birds and bats as wild reservoirs of $N$. risticii (Pusterla et al., 2003; Gibson et al., 2005). Thus, this study 
does not exclude the possibility of different hosts participating in the equine neorickettsiosis transmission chain in Brazil.

In Brazil, the acute phase of this disease was reported just in the southern region, where the climate is comparable with American states (Dutra et al., 2001; Coimbra et al., 2006). In other Brazilian regions, only serological evidence of $N$. risticii exists (Ferrão et al., 2007; Moreira et al., 2013). This serological evidence demonstrates that the animal has been exposed to the bacterium even though the agent has not been directly identified. This constitutes the main critical point in the understanding of the epidemiological chain of equine neorickettsiosis in the studied region. The absence of bacterial DNA might be explained by little or no movement of $N$. risticii in the Itaguaí microregion. Further studies are still needed using a larger sampling of snails, at different seasonal periods to confirm the low occurrence or the absence of $N$. risticii in these hosts in studied region.

\section{CONCLUSION}

It was not possible to identify which species of snails and trematodes are participating in the transmission chain of $N$. risticii to horses in the Itaguaí microrregion, state of Rio de Janeiro, Brazil.

\section{ACKNOWLEDGEMENTS}

The authors acknowledge financial support received from the 'Carlos Chagas Filho' Fundação de Apoio à Pesquisa do Estado do Rio de Janeiro (FAPERJ) and the Coordenação de Aperfeiçoamento de Pessoal de Nível Superior (CAPES). The authors are also grateful to DSc. Silvana Aparecida Rogel Carvalho Thiengo for the snail identification (Laboratório Nacional de Referência em Malacologia do Instituto Oswaldo Cruz).

\section{REFERENCES}

AYRES, M.; AYRES, M. Jr.; AYRES, D.L. BioEstat 5.0: aplicações estatísticas nas áreas das ciências biológicas e médicas. 5.ed. Belém: Sociedade Civil Mamirauá, 2007. 380p.
BAIRD, J.D.; ARROYO, L.G. Historical aspects of Potomac horse fever in Ontario (1924-2010). Can. Vet. J., v.54, p.565-572, 2013.

BARLOUGH, J.E.; REUBEL, G.H.; MADIGAN, J.E. et al. Detection of Ehrlichia risticii, the agent of Potomac horse fever, in freshwater stream snails (Pleuroceridae: Juga spp.) from northern California. Appl. Environ. Microbiol., v.64, p.2888-2893, 1998.

CHAE, J.S.; KIM, E.H.; KIM, M.S. et al. Prevalence and sequence analyses of Neorickettsia risticii. Ann. N.Y. Acad. Sci., v.990, p.248-256, 2003.

CHAE, J.S.; PUSTERLA, N.; JOHNSON, E. et al. Infection of aquatic insects with trematode metacercariae carrying Ehrlichia risticii, the cause of Potomac horse fever. J. Med. Entomol., v.37, p.619$625,2000$.

COIMBRA, H.S. Ocorrência clínica da Erliquiose monocítica equina e pesquisa de formas jovens de trematódeos em Heleobia spp (Mollusca: Hydrobiidae) em terras baixas da encosta sudeste do Rio Grande do Sul. 2010. 48f. Tese (Doutorado em Ciências - Área de Veterinária Preventiva, Sanidade Animal) - Faculdade de Veterinária, Universidade Federal de Pelotas, Pelotas, RS.

COIMBRA, H.S.; FERNANDES, C.; SOARES, M.P. et al. Erliquiose monocítica equina no Rio Grande do Sul: aspectos clínicos, anátomo-patológicos e epidemiológicos. Pesqui. Vet. Bras., v.26, p.97-101, 2006.

COIMBRA, H.S.; SCHUCH, L.F.D.; VEITENHEIMER-MENDES, I.L. et al. Neorickettsia (Ehrlichia) risticii no sul do Brasil: Heleobia spp. (Mollusca: Hydrobilidae) e Parapleurolophocecous cercariae (Trematoda: Digenea) como possíveis vetores. Arq. Inst. Biol., v.72, p.325-329, 2005.

COUTINHO, J.O. Índices de infestação natural dos planorbídeos pelas cercárias do Schistosoma mansoni na cidade do Salvador-Bahia. An. Fac. Med. São Paulo, v.25, p.29-53, 1950.

DUMLER, J.S.; BARBET, A.F.; BEKKER, C.P.J. et al. Reorganization of genera in the families rickettsiaceace and anaplasmataceace in the order rickettsiales; unification of some species of Ehrlichia with Anaplasma, Cowdria with Ehrlichia and Ehrlichia with Neorickettsia, descriptions of six new species combinations and designation of Ehrlichia equi and BHGE agent as subjective synonyms of Ehrlichia phagocytophila. Int. J. Syst. Evol. Microbiol., v.51, p.2145-2165, 2001.

DUTRA, F.; SCHUCH, L.D.F.; DELUCCHI, E. et al. Equine monocytic Ehrlichiosis (Potomac horse fever) in 51 horses in Uruguay and southern Brazil. J. Vet. Diagn. Invest., v.13, p.433-437, 2001. 
FERRÃO, C.M.; ABOUD-DUTRA, A.E.; LOPES, R.S. et al. Equine monocytic ehrlichiosis (EME) in Rio de Janeiro state, Brazil. Arq. Bras. Med. Vet. Zootec., v.59, p.1575-1578, 2007.

FREITAS, M.G. Helmintologia veterinária. 3.ed. Belo Horizonte: Rabelo, 1977. 396p.

GIBSON, K.E.; RIKIHISA, Y.; ZHANG, C. et al. Neorickettsia risticii is vertically transmitted in the trematode Acanthatrium oregonense and horizontally transmitted to bats. Environ. Microbiol. v.7, p.203212, 2005.

GREIMAN, S.E; TKACH, V.V.; VAUGHAN, J.A. Transmission rates of the bacterial endosymbiont, Neorickettsia risticii, during the asexual reproduction phase of its digenean host, Plagiorchis elegans, within naturally infected lymnaeid snails. Parasitol. Vectors, v.6, p.1-7, 2013.

HOLLAND, C.J.; RISTIC, M.; COLE, A.I. et al. Isolation, experimental transmission, and characterization of causative agent of Potomac horse fever. Science, v.35, p.524-526, 1985.

KANTER, M.; MOTT, J.; OHASHI, N. et al. Analysis of 16S rRNA and 51-kilodalton antigen gene and transmission in mice of Ehrlichia risticii in virgulate trematodes from Elimia livescens snails in Ohio. $J$. Clin. Microbiol., v.38, p.3349-3358, 2000

MADIGAN, J.E.; PUSTERLA, N.; JOHNSON, E. et al. Transmission of Ehrlichia risticii, the agent of Potomac horse fever, using naturally infected aquatic insects and helminth vectors: preliminary report. Equine Vet. J., v.32, p.275-279, 2000.

MOREIRA, L.M.C.; CARDOSO, K.M.; ABOUDDUTRA, A.E. et al. Frequency of equine monocytic ehrlichiosis (EME) in Brazil. Pesqui. Vet. Bras., v.33, p.697-699, 2013

MOTT J.; MURAMATSU Y.; SEATON E. et al. Molecular analysis of Neorickettsia risticii in adult aquatic insects in Pennsylvania, in horses infected by ingestion of insects, and isolated in cell culture. $J$. Clin. Microbiol., v.40, p.690-693, 2002.

PALMER, J.E.; WHITLOCK, R.H.; BENSON, C.E. Equine ehrlichial colitis (Potomac horse fever): recognition of the disease in Pensylvania, New Jersey, New York, Ohio, Idaho and Connecticut. J. Am. Vet Med. Assoc., v.189, p.197-199, 1986.
PARK, B.K.; KIM, M.; KIM, E. et al. Identification of trematode cercariae carrying Neorickettsia risticii in freshwater stream snails. Ann. N.Y. Acad. Sci., v.990, p.239-247, 2003.

PUSTERLA, N.; HAGERTY, D.; MAPES, S. et al. Detection of Neorickettsia risticii from various freshwater snail species collected from a district irrigation canal in Nevada county, California. Vet. J., v.197, p.489-491, 2013.

PUSTERLA, N.; JOHNSON, E.; CHAE, J. et al. Infection rate of Ehrlichia risticii, the agent of Potomac horse fever, in freshwater strem snails (Juga yrekaensis) from northern California. Vet. Parasitol. v.92, p.151-156, 2000a.

PUSTERLA, N.; JOHNSON, E.M.; CHAE, J.S. et al. Digenetic trematodes Acanthatrium sp. and Lecithodendrium sp., as vectors of Neorickettsia risticii, the agent of Potomac horse fever. $J$. Helminthol., v.77, p.335-339, 2003.

PUSTERLA, N.; LEUTENEGGER, C.M.; SIGRIST, B. et al. Detection and quantitation of Ehrlichia risticii genomic DNA in infected horses and snails by realtime PCR. Vet. Parasitol. v.90, p.129-135, 2000 b.

RIKIHISA, Y., PERRY, B.D.; CORDES, D.O. Rickettsial link with acute equine diarrhea. Vet. Rec., v.115, p.550-554, 1984.

ROIER E.C.R. Neorickettsia risticii: aspectos clínicos, hematológicos, sorológicos e moleculares em equinos na microrregião de Itaguaí, Rio de Janeiro, Brasil. 2011. 61f. Tese (Doutor em ciências área de concentração, Parasitologia Veterinária) Universidade Federal Rural do Rio de Janeiro, Seropédica, RJ.

THIENGO, S.C.; FERNANDEZ, M.A.; BOAVENTURA, M.F. et al. Freshwater snails and Sschistosomiasis mansoni in the state of Rio de Janeiro, Brazil: I - metropolitan mesoregion. Mem. Inst. Oswaldo Cruz, v.96, p.177-184, 2001.

VAN DER KOLK, J.H.; BERNADINA, W.E; VISSER, I.J. A horse seropositive for Ehrlichia risticii. Tijdschr. Diergeneeskd., v.116, p.69-72, 1991. 